\title{
Impact of Emotional Style on Academic Goals in Pandemic Times
}

\author{
Jessica Paola Palacios Garay ${ }^{1}$, Jorge Luis Escalante ${ }^{2}$, Juan Carlos Chumacero Calle ${ }^{2}$, Inocenta Marivel Cavarjal \\ Bautista $^{3}$, Segundo Perez-Saavedra ${ }^{3} \&$ Jose Nieto-Gamboa $^{3}$ \\ ${ }^{1}$ Universidad Norbert Wiener, Lima, Perú \\ ${ }^{2}$ Universidad de Lima, Lima, Perú \\ ${ }^{3}$ Universidad César Vallejo, Lima, Perú \\ Correspondence: Jessica Paola Palacios Garay, Universidad Norbert Wiener, Lima, Perú.
}

Received: August 20, 2020

Accepted: October 15, 2020

Online Published: November 2, 2020

doi:10.5430/ijhe.v9n9p21

URL: https://doi.org/10.5430/ijhe.v9n9p21

\begin{abstract}
The objective of the present study was to determine the incidence of university students' emotional style on the dimensions of academic goals (academic goals, learning goals, achievement goals and social reinforcement goals). For this study, 780 students of the fifth and sixth cycle of the Health Sciences School at a private university in Lima were chosen.

In this quantitative study, of a substantive type, and a causal correlational cross-sectional non-experimental design, The Emotional Style Questionnaire (ESQ) was administered and for academic goals the questionnaire of the same name (CMA). The results evidenced the significant incidence of emotional style in the academic goals of university students with $72.1 \%$; because the reason of plausibility of the logistic model $(\mathrm{p}<0.05)$ fits well with the data (Deviation with $\mathrm{p}<0.05$ ).
\end{abstract}

Keywords: emotional style, academic goals, learning goals, achievement goals, social reinforcement goals, university students

\section{Introduction}

The COVID-19 pandemic appeared in Wuhan City (China) and then spread worldwide; a situation that nobody expected, breaking routines and lifestyles. This situation has shaken up and put at risk the health of many people, contaminating a large part of the world's population; this endemic incident has forced governments of various countries to take measures and actions for the prevention as well as the intervention on this disease, until now, with certain success; it is hoped that the large laboratories of the world will be able to discover a vaccine soon.

This pandemic has brought about new learning, such as the necessary personal distancing, in addition to remote education for all levels of the educational system. This "new normality" has generated emotional and psychological impacts on families expressed in episodes of anxiety, depression and, some cases, of suicide (Alfaro, 2020). In the educational field, the forms of teaching have been restructured at all levels, especially at the university level. This non-presential education (On line) has been imposed as an alternative modality to continue sustaining the diverseof formative, educational and even labor systems. Teachers have had to prioritize purposes and make incursions into virtual modalities that allow them to maintain social educational links with their students, without falling into a mere transfer of information (Finkelstein, 2020).

Emotions, as a consequence of this disease, are destabilizing the psychological balance of people, seriously compromising the lifestyle. The emotional style is a recurrent way of reacting to events, having a very significant relevance for the human being. Rumination measures the propensity of people to worry about irritating situations that occurred before, as well as worry about previous unpleasant circumstances or occasions. They also worry about those that may occur. Emotional inhibition refers to the act of repressing feelings, experiencing the difficulty of discovering or expressing one's feelings and emotions, as well as seeking out others to obtain information or be heard when faced with different demanding contexts. In this regard, Park, Edmondson, and Lee (2012) suggest that 
restructuring in goal orientations contributes to academic success because coping strategies are better suited to contextual needs and the degrees of sustained effort required by university classrooms.

At various universities, competency-based educational models are being adopted, bringing about changes in institutional, curricular, and academic development dynamics. This model of remote learning is characterized by its self-regulation; its effectiveness in the development of academic goals is based on cognitive, motivational and behavioral processes (Torrano and Soria, 2017). Deep reflections are required, under the approach of the social cognitive theory of Bandura (2001) and the theories of learning proposed by Zimmerman (2013), who affirms that it is important to evaluate the role of self-regulation, self-efficacy of learning and academic goals in university students; that is to say, university students should self-regulate their learning, guided by well-consolidated academic goals.

These academic goals imply organization and regulation of behavior to achieve a certain goal (Valle, Rodríguez, Cabanach, Núñez, González and Rosario, 2009). Pool and Martínez (2013) point out that the goals refer to the results that students wish to achieve; furthermore, it is the students themselves who must guide them according to their interests; therefore, it implies obtaining learning in the process.

In the field of motivation, different types of academic goals are proposed; in the beginning, the two-dimensional approach in which two different forms of contributions is presented: learning or mastery goals and performance or outcome/achievement goals (Dweck and Leggett, 1988 and Nichols, 1984). On the other hand, both Elliot and Harackiewicz (1996) and Pintrich and Schunk (2006) distinguished learning goals that are related to forms of deep processing and performance goals that are related to good performance in order to obtain better results, and those of failure avoidance that are related to superficial processing (Elliot, McGregor and Gablel, 1999).

The goals based on oneself, the goals based on others and the goals of the task approach would predict enjoyment. Task-focused goals negatively predict boredom (Luftenegger, Spiel, Klug \& Schober, 2016).

Both Ramudo (2015) and Ramudo, Brenlla, Barca and Peralbo (2017) reported that goals enable adequate levels of knowledge and/or skills about a subject, or on the contrary poor academic performance. In conclusion, the goals present specific characteristics, that can be adapted in certain areas, but not in others. Furthermore, it was found that students do not choose only one type of goal; on the contrary, they could adopt several in order to be involved in the learning process (Barca, Almeida, Porto, Peralbo and Brenlla, 2012).

Goals are not the same, but they respond to the academic stages of university students, as well as to their personal and social development and, as a consequence, they can rethink and restate in their directionality.

In relation to the above, the objective stated was to determine the incidence of the students' emotional style on their academic goals: those related to learning, social reinforcement and achievement. At present, according to the reviews carried out, there are few studies that have considered these variables; the scarce literature on the emotional style variable and a few works on academic goals in university students justify the present study.

\section{Emotions in the Learning Process}

Emotions have an important impact on the cognitive process that includes perceptions, attention, learning, memorization, reasoning and problem solving. Emotion has a particular impact on attention and behavior. These attentional controls are linked to the learning process because of intrinsically limited attention skills and focus on important information. Emotions guarantee codifications and make information possible in an efficient way. On the other hand, the effect of emotions on learning and memory is not univocal because research reports that emotions improve or deteriorate learning and long-term memory. Thus, they depend on many factors that influence the psychism of people (Tyng, Amin, Saad and Malik, 2017).

Recent neuroimaging results have indicated that the tonsils and prefrontal cortex cooperate with the temporal lobe in an integrated manner that enables (i) the memory consolidations that modulate the tonsils; (ii) the prefrontal cortex that facilitates memory encoding and shaping; and (iii) the hippocampus for learning success and retention. The hierarchies and controls of both circular emotions and cognitive regulations (ascending and descending influences) should be reviewed. Within the brain, the importance of emotional and cognitive processing is understood. This review highlights an evolutionarily basic approach to emotions in order to understand the effects of emotions on learning, memory and the roles of functions performed by various areas of the brain and the mutual interaction of functions with emotional processing. In addition, the current state of knowledge about the impacts of emotions on memory was considered and the implications for educational settings were mapped. In addition, the effects of 
memory-enhancing emotions were elucidated; neuroimaging findings broaden understandings of the emotional influence on the learning and memory process; this knowledge may be useful for future effective educational curriculum and design to provide an appropriate learning environment for both traditional "live" in the classroom and "virtual" through online educational technologies (Tyng et al., 2017).

\subsection{Emotional Rumination and Inhibition}

Derek, Guarino, Borril, and Forbes (2011) hypothesized that emotional rumination and inhibition may predispose individuals to stress-related diseases. It has subsequently been argued that stress can be more appropriately defined as rumination because it is dominated by obsessive ideas.

The role of emotional inhibition in health and well-being has been extensively researched; for example, Pennebaker, Colder, \& Sharp (1990) found that expressing emotions about thoughts and feelings associated with adaptive processes led to adaptation to the environment (Petrie, Booth, \& Pennebaker, 1998).

Emotional inhibition has also been associated with moderation of health status, although results have been less clear than for rumination; for example, a study of changes in health status during an adaptation period showed that while the main effect of rumination was significant, neither the main effect of inhibition nor the rumination-inhibition interaction was significant (Roger, 1996).

\section{Academic Goals of University Students}

According to Dweck's model (1986), Hayamizu, Ito and Yohiazaki (1989) indicated three types of goals: (1) learning, (2) achievement and (3) social reinforcement; the first is associated with the goal of improving competencies; on the other hand, achievement and social reinforcement are related to performance goals (English, Martínez, Valle, García y Ruiz, 2016). Learning goals guide students' actions in the development of their competencies; that is, learning and skill improvement actions are mobilized; however, students with goal orientation towards results mobilize competence and academic strategies for the achievement of good grades. Social reinforcement goals focus on getting recognition or approval from teachers and families. Academic goals are not exclusive since students' activities may be directed in one way or another according to the environment, personal characters, or the challenges imposed by particular activities (Dull, Schleifer \& McMillan, 2015; Gamez, Marrero, Diaz \& Urrutia, 2015).

The motivational profile with predominance of learning goals is linked to improved performance in key self-efficacy roles (Valle et al., 2015), including self-concepts in academics that significantly influence both goal choices and the need for autonomy, competencies, and attachments (Gámez et al., 2015). Studies with undergraduates in different careers revealed that goal orientation had positive impacts on grades and self-efficacy (Dull et al., 2015). From this longitudinal perspective, Pulkka and Niemivirta (2013) highlighted the stability of goal orientation in students. Even at the presence of changes in orientation, succesful learning would take place.

Likewise, the study by Cerezo, Fernández, Amieiro, Valle, Rosario and Núñez (2018) showed that knowledge of self-regulation strategies for learning significantly improves self-efficacy in the use of these strategies, as long as they are associated with learning goals. Despite this, students have problems in effectively addressing academic goals because they are susceptible to motivational interventions. Cross-cultural interventions in countries such as Portugal, Mozambique, Spain and Chile succeed in promoting the use of self-regulated learning strategies to achieve academic goals (Rosário, Núñez, Trigo, Guimarraes, Fernández, Cerezo, Fuentes, Orellana, Santibáñez, Fulano, Ferreira and Figueiredo, 2015). Given the above, it is important to recognize that universities, in addition to promoting processes of control over students' thoughts, actions, emotions and motivations, provide direct and real experiences, with the aim of achieving autonomous and deep learning (Baker, 2017; Zimmerman, 2013).

Positive self-efficacy constitutes the fundamental element in the implications of students since, together with the process of self-regulation of learning, they enhance the goals in improving their personal skills for their integral development; therefore, universities must strengthen these mechanisms (Beatson, Berg \& Smith, 2018). In light of the above, evaluations of the relationship between self-regulation of learning and general self-efficacy with academic goals provide new insights into how students face university demands. In an effective manner, for meaningful and autonomous learning it is not enough to know only the contents of the subjects; but the disposition, confidence, efforts and persistence for the successful achievement of the academic challenges. 


\subsection{Academic Goals and Their Dimensions}

Academic goals are classified into learning goals, social reinforcement goals, and achievement goals (Durán and Arias, 2015). Learning goals or mastery measure the tendency of students to seek to increase their own competencies through the acquisition and mastery of new skills, knowledge, abilities, and improvement in the execution of learning tasks; students learn from their mistakes by seeking significant learning, facing difficulties.

Social reinforcement goals measure the tendency of students to learn with the purpose of obtaining approval and avoiding rejection by teachers and parents; university students require a positive evaluation of their challenges and abilities to achieve what is expected.

Achievement or performance goals measure the tendency of students to learn for the purpose of obtaining good test scores. Students focus more on their test scores and how they do it; in this case, mistakes are failures that directly affect the student.

\section{Method}

The study was carried out under the quantitative approach, type of substantive study, having as sample 780 university students of the Health Sciences Faculty of a private university that are studying the fifth and sixth cycle (50.5\% women and $49.5 \%$ men), who agreed to participate voluntarily.

\subsection{Instruments}

The instruments used were the Emotional Style Questionnaire (ESQ) which consists of 39 items, its original true-false dichotomous response scale with 21 items for measuring the emotional inhibition dimension and 18 for measuring rumination with a reliability of 0.96 according to the KR-20. For the academic goals, the Academic Goals Questionnaire (AQQ) was used, which consists of 16 items having three dimensions: learning goals, social reinforcement goals, and achievement goals in a scale in which each item is scored from 1 to 5 , AA = Almost always; $\mathrm{A}=$ Always; $\mathrm{S}=$ Sometimes; $\mathrm{R}=$ Rarely; $\mathrm{N}=$ Never, with a reliability of 0.901 through Cronbach's Alpha.

\subsection{Procedure}

First, the corresponding permission was requested from the university authorities for the application of the instruments. Subsequently, participants who agreed to do so voluntarily were guaranteed confidentiality of the information and compliance with the ethical aspects of the study. Finally, the students answered two questionnaires virtually using Google forms from a drive created by the researchers to collect the data.

It was found that, in the Kolmogorov Smirnov normality test, values were obtained by which the non-normal distribution of variables was established and it was decided to use a non-parametric test: ordinal logistic regression.

\subsection{Results}

Table 1. Information on model adjustments that explains the incidence of emotional style on academic goals

\begin{tabular}{lllll}
\hline Model & $\begin{array}{l}\text { Verisimilitude } \\
\text { logarithms-2 }\end{array}$ & Chi2 & Gl & Sig. \\
\hline Intersections only & 847,440 & & & \\
Final & 65,921 & 781,520 & 4 &, 000 \\
Linking functions: Logit. & & & & \\
\hline
\end{tabular}

In the test of contrasts of the ratio of verisimilarities, it was pointed out that, as a logistic model, it presents significance $(x 2=781,520 ; \mathrm{p}<0.05)$; that is, the emotional style influences the academic goals. 
Table 2. Goodness of fit and Pseudo R2 of the model that explains the incidence of emotional style on academic goals

\begin{tabular}{llllll}
\hline & Chi2 & gl & Sig. & \multicolumn{2}{l}{ Pseudo R square } \\
\hline Pearson & 42,690 & 12 &, 000 & Cox y Snell &, 633 \\
Deviations & 32,740 & 12 &, 001 & Nagelkerke &, 721 \\
Linkingfunctions: Logit. & & & McFadden &, 477 \\
\hline
\end{tabular}

Linkingfunctions: Logit.

Once the regression model has been built, the quality of adjustments of pre-set values by the model of the observed value is checked. The deviation $(\mathrm{x} 2=32,740)$ showed a $\mathrm{p}<0.05$; the regression model that explains the incidence of the emotional style in the academic goals had the result of Pseudo - R2 Nagelkerke is 0.721 ; that is, there is a $72.1 \%$ incidence of the emotional style in the academic goals.

Table 3. Estimation of the parameters of the model that explains the incidence of the emotional style in the academic goals

\begin{tabular}{|c|c|c|c|c|c|c|c|c|}
\hline \multicolumn{9}{|c|}{ Parameter estimates } \\
\hline & & \multirow[b]{2}{*}{ Estimation } & \multirow[b]{2}{*}{ Dev. Error } & \multirow[b]{2}{*}{ Wald } & \multirow[b]{2}{*}{ gl } & \multirow[b]{2}{*}{ Sig. } & \multicolumn{2}{|c|}{$95 \%$ confidence interval } \\
\hline & & & & & & & Lower limit & Upper limit \\
\hline \multirow[t]{2}{*}{ Threshold } & {$[$ Met_aca $=1]$} & 21,184 & 610 & 1205,411 & 1 & ,000 & 19,988 & 22,380 \\
\hline & [Met_aca $=2]$ & 24,177 & ,650 & 1383,203 & 1 &, 000 & 22,903 & 25,451 \\
\hline \multirow[t]{6}{*}{ Location } & {$[$ Rum $=1]$} & 5,497 & ,626 & 77,142 & 1 &, 000 & 4,270 & 6,723 \\
\hline & [Rum=2] &, 520 & ,654 & ,631 & 1 &, 427 &,- 763 & 1,802 \\
\hline & {$[$ Rum $=3]$} & $0^{\mathrm{a}}$ & . & . & 0 & . & . & . \\
\hline & [Inh_emo=1] & 18,574 &, 244 & 5780,405 & 1 &, 000 & 18,096 & 19,053 \\
\hline & [Inh_emo=2] & 17,530 &, 000 & . & 1 & . & 17,530 & 17,530 \\
\hline & [Inh_emo=3] & $0^{\mathrm{a}}$ & . & . & 0 & . & . & . \\
\hline \multicolumn{9}{|c|}{ Linking functions: Logit. } \\
\hline
\end{tabular}

The table indicated that emotional inhibition (Wald $=5780,405 ; \mathrm{p}=0,000<0.05$ ) better predicted academic goals. 
Table 4. Information on model adjustments that explains the incidence of emotional style on the dimensions of academic goals

\begin{tabular}{|c|c|c|c|c|}
\hline \multicolumn{5}{|c|}{ Information on adjusting the emotional style models in the learning goals } \\
\hline Model & Logarithm of the verisimilitude -2 & Chi2 & Gl & Sig. \\
\hline Intersections only & 735,589 & & & \\
\hline Final & 103,953 & 631,636 & 4 & 000 \\
\hline \multicolumn{5}{|l|}{ Linkingfunctions: Logit. } \\
\hline \multicolumn{5}{|c|}{ Information on adjusting the emotional style models in the achievement goals } \\
\hline Model & Logarithm de la verisimilitude -2 & Chi2 & Gl & Sig. \\
\hline Intersectionsonly & 634,590 & & & \\
\hline Final & 97,564 & 537,027 & 4 & 000 \\
\hline \multicolumn{5}{|l|}{ Linkingfunctions: Logit. } \\
\hline \multicolumn{5}{|c|}{ Information on adjusting the emotional style models in the emocionalstyle social reinforcement goals } \\
\hline Model & Logaritmos de la verosimilitud -2 & Chi2 & Gl & Sig. \\
\hline Intersectionsonly & 703,424 & & & \\
\hline Final & 83,130 & 620,294 & 4 & ,000 \\
\hline Linkingfunctions: Logit. & & & & \\
\hline
\end{tabular}

In the test of contrasts of the ratio of verisimilarities, it was pointed out that, as a logistic model, it presents significance ( $\mathrm{x} 2=631,636 ; \mathrm{p}<0.05)$; that is, the emotional style influences the learning goals; as a logistical model it presented significance $(\mathrm{x} 2=97,564 ; \mathrm{p}<0.05)$, that is, the emotional style influences the achievement goals; as a logistical model it presented significance $(\mathrm{x} 2=620,294 ; \mathrm{p}<0.05)$, that is, the emotional style influences the social reinforcement goals.

Table 5. Goodness of fit of the model that explains the incidence of emotional style on academic goals

\begin{tabular}{|c|c|c|c|}
\hline \multicolumn{4}{|c|}{ Goodness of emotional style adjustments in learning goals } \\
\hline & Chi2 & gl & Sig. \\
\hline Pearson & 117,234 & 12 & ,000 \\
\hline Deviation & 60,727 & 12 & , 000 \\
\hline \multicolumn{4}{|c|}{ Linkingfunctions: Logit. } \\
\hline \multicolumn{4}{|c|}{ Goodness of emotional style adjustments in achievement goals } \\
\hline & Chi2 & $\mathrm{gl}$ & Sig. \\
\hline Pearson & 65,754 & 12 & ,000 \\
\hline Deviation & 52,358 & 12 & 000 \\
\hline \multicolumn{4}{|c|}{ Linkingfunctions: Logit. } \\
\hline \multicolumn{4}{|c|}{ Goodness of emotional style adjustments in social reinforcement goals } \\
\hline & Chi2 & $\mathrm{gl}$ & Sig. \\
\hline Pearson & 47,820 & 12 & ,000 \\
\hline Deviation & 37,732 & 12 & ,000 \\
\hline Linkingfun & & & \\
\hline
\end{tabular}


Based on the regression model, the quality of adjustments of pre-set values by the model of the observed value is checked. The deviation $(\mathrm{x} 2=60,727)$ showed a $\mathrm{p}<0.05$, therefore, the incidence of the emotional style in the learning goals is confirmed; the deviation $(\mathrm{x} 2=52,358)$ showed a $\mathrm{p}<0.05$, therefore, the incidence of the emotional style in the achievement goals is confirmed; finally, the deviation $(x 2=37,732)$ showed a $p<0.05$, therefore, the incidence of the emotional style in the social reinforcement goals is confirmed.

Table 6. Pseudo R - square of the model that explains the incidence of the emotional style in the academic goals

\begin{tabular}{ll}
\hline Pseudo R square of emotional style in learning goals & \\
\hline Cox y Snell &, 555 \\
Nagelkerke &, 635 \\
McFadden &, 391 \\
Linkingfunctions: Logit. & \\
\hline Pseudo R square of emotional style in achievement goals \\
\hline Cox y Snell &, 498 \\
Nagelkerke &, 570 \\
McFadden &, 333 \\
Linkingfunctions: Logit. & \\
\hline Pseudo R square of emotional style in social reinforcement goals \\
\hline Cox y Snell &, 549 \\
Nagelkerke &, 624 \\
McFadden &, 377 \\
Linkingfunctions: Logit. & \\
\hline
\end{tabular}

The result of Pseudo - R2 Nagelkerke is 0.635 , indicated that the proposed model explained in $63.5 \%$ the incidence of the emotional style in the learning goals; the result of Pseudo - R2 Nagelkerke is 0.570 , indicated that the proposed model explained in 57\% the incidence of the emotional style in the achievement goals, and the result of Pseudo - R2 Nagelkerke is 0.624 , indicated that the proposed model explained in $62.4 \%$ the incidence of the emotional style in the social reinforcement goals.

Table 7. Estimation of the parameters of the model that explains the incidence of the emotional style in the academic goals

\begin{tabular}{|c|c|c|c|c|c|c|c|c|}
\hline \multicolumn{9}{|c|}{ Parameter estimates of emotional style in learning goals } \\
\hline & & \multirow[b]{2}{*}{ Estimación } & \multirow[b]{2}{*}{ Desv. Error } & \multirow[b]{2}{*}{ Wald } & \multirow[b]{2}{*}{$\mathrm{gl}$} & \multirow[b]{2}{*}{ Sig. } & \multicolumn{2}{|c|}{ 95\% Confidence interval } \\
\hline & & & & & & & Lower limit & Upper limit \\
\hline \multirow[t]{2}{*}{ Threshold } & [Met_Ap $=1]$ & 3,590 & ,630 & 32,450 & 1 & 000 & 2,355 & 4,825 \\
\hline & [Met_Ap $=2]$ & 6,807 & ,660 & 106,441 & 1 & ,000 & 5,514 & 8,100 \\
\hline \multirow[t]{6}{*}{ Location } & [Rum=1] & 4,107 &, 400 & 105,496 & 1 & ,000 & 3,324 & 4,891 \\
\hline & [Rum=2] & ,294 & ,405 &, 526 & 1 & ,468 &,- 501 & 1,088 \\
\hline & {$[$ Rum=3] } & $0^{\mathrm{a}}$ & . & . & 0 & . & . & . \\
\hline & [Inh_emo=1] & 2,127 & 675 & 9,920 & 1 & ,002 & ,803 & 3,451 \\
\hline & [Inh_emo=2] & 1,024 & ,682 & 2,255 & 1 & ,133 &,- 313 & 2,361 \\
\hline & [Inh_emo=3] & $0^{\mathrm{a}}$ & . & . & 0 & . & . & . \\
\hline
\end{tabular}

Linking functions: Logit.

a. This parameter is set to zero because it is redundant 


\begin{tabular}{|c|c|c|c|c|c|c|c|c|}
\hline \multicolumn{9}{|c|}{ Parameter estimates of emotional style in achievement goals } \\
\hline & & \multirow[b]{2}{*}{ Estimación } & \multirow[b]{2}{*}{ Desv. Error } & \multirow[b]{2}{*}{ Wald } & \multirow[b]{2}{*}{ gl } & \multirow[b]{2}{*}{ Sig. } & \multicolumn{2}{|c|}{ 95\% Confidence interval } \\
\hline & & & & & & & Lower limit & Lower limit \\
\hline \multirow[t]{2}{*}{ Threshold } & {$[$ Met_log $=1]$} & 3,411 & ,606 & 31,642 & 1 & ,000 & 2,223 & 4,600 \\
\hline & [Met_log = 2] & 5,993 & ,626 & 91,628 & 1 & 000 & 4,766 & 7,220 \\
\hline \multirow[t]{6}{*}{ Location } & [Rum=1] & 3,317 &, 347 & 91,362 & 1 & ,000 & 2,637 & 3,997 \\
\hline & [Rum=2] &,- 315 &, 370 &, 726 & 1 &, 394 & $-1,040$ & ,410 \\
\hline & [Rum=3] & $0^{\mathrm{a}}$ & $\cdot$ & . & 0 & . & . & $\cdot$ \\
\hline & [Inh_emo=1] & 2,115 & ,657 & 10,366 & 1 & ,001 &, 828 & 3,403 \\
\hline & [Inh_emo=2] & 1,539 & ,657 & 5,496 & 1 & ,019 &, 252 & 2,826 \\
\hline & [Inh_emo=3] & $0^{\mathrm{a}}$ & . & . & 0 & . & . & . \\
\hline
\end{tabular}

Linking functions: Logit.

a. This parameter is set to zero because it is redundant.

\begin{tabular}{|c|c|c|c|c|c|c|c|c|}
\hline \multicolumn{9}{|c|}{ Parameter estimates of emotional style in social reinforcement goals } \\
\hline & & \multirow[b]{2}{*}{ Estimation } & \multirow[b]{2}{*}{ Dev. Error } & \multirow[b]{2}{*}{ Wald } & \multirow[b]{2}{*}{$\mathrm{gl}$} & \multirow[b]{2}{*}{ Sig. } & \multicolumn{2}{|c|}{ 95\% Confidence interval } \\
\hline & & & & & & & Lower limit & Upper limit \\
\hline \multirow[t]{2}{*}{ Threshold } & [Met_ref $=1]$ & 3,022 & ,496 & 37,190 & 1 & ,000 & 2,051 & 3,993 \\
\hline & [Met_ref $=2]$ & 5,114 &, 518 & 97,623 & 1 & ,000 & 4,100 & 6,129 \\
\hline \multirow[t]{6}{*}{ Location } & [Rum $=1]$ & 4,213 & ,429 & 96,263 & 1 & ,000 & 3,371 & 5,055 \\
\hline & [Rum=2] & ,408 & ,442 &, 850 & 1 & ,356 &,- 459 & 1,275 \\
\hline & [Rum=3] & $0^{\mathrm{a}}$ & . & . & 0 & . & . & . \\
\hline & [Inh_emo=1] & 1,171 & ,566 & 4,283 & 1 & ,038 &, 062 & 2,280 \\
\hline & [Inh_emo=2] &, 074 &, 575 &, 016 & 1 & ,898 & $-1,053$ & 1,200 \\
\hline & [Inh_emo=3] & $0^{\mathrm{a}}$ & . & . & 0 & . & . & . \\
\hline
\end{tabular}

Linking functions: Logit.

a. This parameter is set to zero because it is redundant.

The table indicated that rumination (Wald $=105,496 ; \mathrm{p}=0,000<0,05$ ) better predicted academic goals; Besides, it indicated that rumination (Wald $=91,362 ; \mathrm{p}=0,000<0,05$ ) gave a prognosis of better achievement goals; and finally rumination (Wald $=96,263 ; p=0,000<0,05$ ) better predicted social reinforcement goals.

\section{Discussion}

The incidence of emotional style on the academic goals of university students was $72.1 \%$; this result coincides with Pintrichand Schunk (2006) and Barca et al. (2012), who state that academic goals can be established as the model or motivational style configured by belief, attribution, affection or feeling, which govern the intentions of what students do or would like to do in an educational context. For this reason, achievement goals and emotions are crucial to students' learning processes and have an impact on their academic outcomes (Hulleman, Schrager, Bodmann and Harackiewicz, 2010 and Goetz and Hall, 2013).

With regard to the first dimension on learning goals, the study showed that the emotional style has a significant impact on 63.5\%; then, it was established that academic goals become vital in the prognosis of persistence because, to the extent that the subject is oriented to learning or mastery, would deploy a more adaptive behavior to the difficulties of the task and, therefore, greater academic integration, which would positively affect persistence. However, in the study, it was found the opposite. On the other hand, academic goals are vital for understanding student motivation (Calderón and Casu, 2011). Durán and Arias (2015) state that goals determine the quantities and 
qualities of learning and study actions as part of the student's cognitive, affective, and behavioral reaction to the outcome of successes or failures (Barca et al., 2012). College motivation and performance are two components that impact academic goals, being of vital importance for meaningful learning and skills development. In conclusion, Valle et al. (2015) verified that students who report goals of approaching learning are those who give greater value to the contents and tasks; in addition, they present higher levels of self-efficacy beliefs and less anxiety before exams.

As for the significant incidence of 57\% of the emotional style on achievement goals, the work of Park et al. (2012) stated that periods of training at university are relevant for the acquisition of self-regulatory skills in response to the demand they pose in adult life, and it is plausible that these restructuring in the orientation of the goals contribute to greater academic success. These results contrast with the study by Sorić, Penezić and Burić (2017), who stated that, in the face of lack of commitment, university students show less psychophysiological response. The vulnerability that is explained in lesser proportion by their involvement and academic commitments is established by the goals of approach and responsibility.

The incidence of emotional style in the social reinforcement goals dimension was 62.4\%; these results are supported by the study of Ling, He, Wei, Cen, Zhou and Zhong, (2016), who concluded that the goal, of intrinsic nature, performs protective effects in the face of the appearance of symptoms of depression, compared with students who are extrinsically oriented to the goals such as social recognition. Likewise, Durán and Arias (2015) pointed out the relevance of the approaches to learning since university students also show goal in an external way (oriented to academic performance), since they favor persistencies within specific training programs. Finally, it should be noted that the profile of goal orientation does not present stable characteristics and the orientations of learning approaches tend to decline after the first and second university subjects, increasing the phenomena of procrastination (Stewart, Stott and Nuttall, 2016). These results are consistent with those of English et al. (2016) since, according to these authors, students with high procrastination towards their classmates are also those who have a greater motivation both to learn and to achieve good academic goals and vice versa.

\section{Conclusion}

It is concluded that academic goals are not exclusive, but should be associated with each other; it is necessary that the university student takes into account the goals of learning, achievement and social reinforcement in the face of the results of success or failure.

The achievement of the academic goals of university students is directly related to the diverse motivations, above all, the emotional ones that are recurrent forms of reacting to events, mainly, the external ones. This pandemic situation affects a significant part of the national population, including university students, since it generates anxiety and, in other cases, depression; as a consequence, students present a low level in terms of academic goals or end up dropping out, cutting or affecting their professional goals. On the other hand, students who manage to overcome difficulties reinforce their confidence, which guarantees that they stay in university and, therefore, they pursue for their academic goals.

As for the aspect of rumination, this academic difficulty of the students is explained by the persistent worries and thoughts when not finding a way out of their difficulties with the consequent academic prejudice and frustration, with this, comes along the difficulty of the achievement and planning of their academic learning when they see they cannot achieve their academic goals and, as a consequence, the abandonment of both the university classrooms and the planned goals.

\section{References}

Alfaro, X. (2020). Gobierno de El Salvador ordena cuarentena domiciliar por 30 días a partir de este sábado. El Diario de Hoy.

Bandura, A. (2001). Social cognitive theory: An agentic perspective. Annual Review of Psychology, 52, 1-26. https://doi.org/10.1146/annurev.psych.52.1.1

Barca, A., Almeida, L., Porto-Rioboo, A., Peralbo-Uzquiano, M., \& Brenlla-Blanco, J. (2012). Motivación escolar y rendimiento: impacto de metas académicas, de estrategias de aprendizaje y autoeficacia. Anales de Psicología, 28(3), 848-859. https://doi.org/10.6018/analesps.28.3.156101

Beatson, N., Berg, D., \& Smith, J. (2018). The Impact of Mastery Feedback on Undegraduate Students' Self-efficacy Beliefs. Studies in Educational Evaluation, 59, 58-66. https://doi.org/10.1016/j.stueduc.2018.03.002 
Calderón, C., \& Casu, G. (2011). Escala de Factores Estructurales de La Clase: Una Medida Para Evaluar Características de la Clase Relacionadas con las Metas Académicas de los Estudiantes. SALUD \& SOCIEDAD, 2(3), 285-296. https://doi.org/10.22199/S07187475.2011.0003.00005

Cerezo, R., Fernández, E., Amieiro, N., Valle, A., Rosário, P., \& Núñez, J. (2018). El Papel Mediador de la Autoeficacia y la Utilidad entre el Conocimiento y el Uso de Estrategias de Autorregulación del Aprendizaje. Revista de Psicodidáctica, 24(1), 1-8. https://doi.org/10.1016/j.psicod.2018.08.001

Derek, R., Guarino, L., Borril, J., \& Forbes, A. (2011). Rumination, inhibition and stress: The construction of a new scale for assessing emotional style. CurrentPsychology, 30(3), 234-244. https://doi.org/10.1007/s12144-011-9117-y

Dull, R., Schleifer, L., \& McMillan, J. (2015). Achievement goal theory: The relationships of accounting students' goal orientations with self-efficacy, anxiety, and achievement. Accounting Education: an international journal, 24(2), 152-174. https://doi.org/10.1080/09639284.2015.1036892

Durán, E., \& Arias, D. (2015). Orientación a las metas académicas, persistencia y rendimiento en estudiantes del Ciclo de Iniciación Universitaria. REDU. Revista de DocenciaUniversitaria, 13(2), $189-206$. https://doi.org/10.4995/redu.2015.5444

Dweck, C. (1986). Motivational process affecting learning. American Psychologist, 41, $1040-1048$. https://doi.org/10.1037/0003-066X.41.10.1040

Dweck, C., \& Leggett, E. (1988). A social-cognitive approach to motivation and personality. Psychological Review, 95, 256-273. https://doi.org/10.1037/0033-295X.95.2.256

Elliot, A., \& Harackiewicz, J. (1996). Approach and avoidance achievement goals and intrisic motivation: A mediational analysis. Journal of Personality and Social Psychology, 70, 461-475. https://doi.org/10.1037/0022-3514.70.3.461

Elliot, A., McGregor, H., \& Gable, S. (1999). Achievement goals, study strategies, and exam performance: A mediational analysis. Journal of Educational Psychology, 91, 549-563. https://doi.org/10.1037/0022-0663.91.3.549

Finkelstein, C. (2020). La enseñanza en la universidad en tiempos de pandemia. https://doi.org/10.25267/Rev_educ_ambient_sostenibilidad.2020.v2.i1.1502

Gámez, E., Marrero, H., Díaz, J., \& Urrutia, M. (2015). Qué esperan encontrar los alumnos en los estudios de Psicología? Metas y motivos personales de los estudiantes en su primer año en la Universidad. Anales de Psicología, 31(2), 589-599. https://doi.org/10.6018/analesps.31.2.171851

Goetz, T., \& Hall, N. (2013). Emotion and achievement in the classroom. Educational psychology handbook series. 192-195. Retrieved from http://nbn-resolving.de/urn:nbn:de:bsz:352-219285

Hayamizu, T., Ito, A., \& Yohiazaki, K. (1989). Cognitive Motivacional Process Mediated by Achievement Goal Tendencies. Japonese Psychological Research, 31, 179-189. https://doi.org/10.4992/psycholres 1954.31.179

Hulleman, C., Schrager, S., Bodmann, S., \& Harackiewicz, J. (2010). A meta-analytic review of achievement goal measures: different labels for the same constructs or different constructs with similar labels? Psychol. Bull, 136, 422-449. https://doi.org/10.1037/a0018947

Inglés, C., Martínez, A., Valle, A., García, J., \& Ruiz, C. (2016). Conducta prosocial y motivación académica en estudiantes españoles de Educación Secundaria. Universitas Psychologica, 10(2), 451-465. https://doi.org/10.11144/Javeriana.upsy10-2.cpma

Ling, Y., He, Y., Wei, Y., Cen, W., Zhou, Q., \& Zhong, M. (2016). Intrinsic and extrinsic goals as moderators of stress and depressive symptoms in Chinese undergraduate students: A multi-wave longitudinal study. BMC Psychiatry, 16(1), 138. https://doi.org/10.1186/s12888-016-0842-5

Luftenegger, M., Spiel, C., Klug, J., \& Schober, B. (2016). Students' achievement goals learning related emotions and academic achievement. Frontiers in Psychology, 7(603), 1-10. https://doi.org/10.3389/fpsyg.2016.00603

Nichols, J. (1984). Achievement motivation: Conceptions of ability, subjective experience, task choice, and performance. Psychological Review, 91, 328-346. https://doi.org/10.1037/0033-295X.91.3.328

Panadero, E., Jönsson, A., \& Botella, J. (2017). Effects of self-assessment on self-regulated learning and self-efficacy: Four meta-analyses. Educational Research Review, 22, 74-98. https://doi.org/10.1016/j.edurev.2017.08.004

Park, C., Edmondson, D., \& Lee, J. (2012). Development of self-regulation abilities as predictors of psychological adjustment across the first year of college. Journal of Adult Development, 19(1), 40-49. https://doi.org/10.1007/s10804-011-9133-z 
Pennebaker, J., Colder, M., \& Sharp, L. (1990). Accelerating the coping process. Journal of Personality and Social Psychology, 58, 528-537. https://doi.org/10.1037/0022-3514.58.3.528

Petrie, K., Booth, R., \& Pennebaker, J. (1998). The immunological effects of thought suppression. Journal of Personality and Social Psychology, 75, 1264-1272. https://doi.org/10.1037/0022-3514.75.5.1264

Pintrich, P. (2000). Multiple goals, multiple pathways: The role of goal orientation in learning and achievement. Journal of Educational Psychology, 92(3), 544-555. https://doi.org/10.1037/0022-0663.92.3.544

Pintrich, P., \& Schunk, D. (2006). Motivación en contextos educativos. Teoría, investigación y aplicaciones. Madrid: Pearson Educación.

Pulkka A., \& Niemivirta, M. (2013). Adult students'achievement goal orientations and evaluations of the learning enviroment: a person-centred longitudinal análisis. EducationalResearch and Evaluation, 19(4), 297-322. https://doi.org/10.1080/13803611.2013.767741

Ramudo, I. (2015). Variables motivacionais, autoeficacia e enfoques de aprendizaxe en relación co ren-demento académico do alumnado de bacharelato (Tesis doctoral). Universidade da Coruña, A Coruña.

Ramudo, I., Brenlla, J., Barca, A., \& Peralbo, M. (2017). Enfoques de aprendizaje, autoeficacia y rendimiento académico. Revista de estudios e investigación en psicología y educación. Extra, 1, 138-142. https://doi.org/10.17979/reipe.2017.0.01.2435

Roger, D. (1996). The role of cognitive rumination, copying styles and self-esteem in moderating adaptational responses to stress. Paper presented at the 8th European Conference on Personality, University of Ghent, July.

Rosário, P., Núñez, J., Trigo, L., Guimarraes, C., Fernández, E., Cerezo, R., Fuentes, S., Orellana, M., Santibáñez, A., Fulano, C., Ferreira, A., \& Figueiredo, M. (2015). Transcultural Analysis of the Effectiveness of a Program to Promote Selfregulated Learning in Mozambique, Chile, Portugal, and Spain. Higher Education Research y Development, 34(1), 173-187. https://doi.org/10.1080/07294360.2014.935932

Rosário, P., R. Mourao, R., Núñez, J. C., González-Pienda, J., Solano, P., \& Valle, A. (2007). Eficacia de un Programa Instruccional para la Mejora de Procesos y Estrategias de Aprendizaje en la Enseñanza Superior. Psicothema, 19(3), 422-427.

Sorić, I., Penezić, Z., \& Burić, I. (2017). The Big Five personality traits, goal orientations, and academic achievement. Learning and Individual Differences, 54, 126-134. https://doi.org/10.1016/j.lindif.2017.01.024

Stewart, M., Stott, T., \& Nuttall, A. (2016). Study goals and procrastination tendencies at different stages of the undergraduate degree. Studies in Higher Education, 41(11), 2028-2043. https://doi.org/10.1080/03075079.2015.1005590

Torrano, F., \& Soria, M. (2017). Diferencias de género y aprendizaje autorregulado: el efecto del rendimiento académico previo. Revista Complutense de Educación, 28(4), 1027-1042. http://doi.org/10.5209/RCED.51096

Tyng, C., Amin, H., Saad, M., \& Malik, A. (2017). The Influences of Emotion on Learning and Memory. Front. Psychol., 24(1). https://doi.org/10.3389/fpsyg.2017.01454

Valle, A., Núñez, J., Cabanach, R., Rodríguez, S., Rosário, P., \& eInglés, C. (2015). Motivational profiles as a combination of academic goals in higher education. Educational Psychology, 35(5), 634-650. https://doi.org/10.1080/01443410.2013.819072

Valle, A., Rodríguez, S., Cabanach, R., Núñez, J., González-Pienda, J., \& Rosário, P. (2009). Metas académicas: Perspectiva histórica y conceptual e implicaciones educativas. Electronic Journal of Research in Educational Psychology, 7(3), 1073-1106. https://doi.org/10.25115/ejrep.v7i19.1358

Zimmerman, B. (2013). From Cognitive Modeling to Self-regulation: A Social Cognitive carreer path. Educational Psychologist, 48(3), 135-147. https://doi.org/10.1080/00461520.2013.794676

\section{Copyrights}

Copyright for this article is retained by the author(s), with first publication rights granted to the journal.

This is an open-access article distributed under the terms and conditions of the Creative Commons Attribution license (http://creativecommons.org/licenses/by/4.0/). 